Elsevier

BBAPRO 33521

\title{
Purification, properties, and oxygen reactivity of $p$-hydroxybenzoate hydroxylase from Pseudomonas aeruginosa
}

\author{
Barrie Entsch ${ }^{1.2}$ and David P. Ballou ${ }^{2}$ \\ 'Department of Biochemistry, Microbiology and Nutrition University of New England, Armidale, N.S.W. (Australia) \\ and ${ }^{2}$ Department of Biological Chemistry, The University of Michigan, Ann Arbor, MI (U.S.A.)
}

(Received 30 August 1989)

Key words: $p$-Hydroxybenzoate hydroxylase; Flavoprotein; Hydroxylase, Oxygenase

The monooxygenase, $p$-hydroxybenzoate hydroxylase (4-hydroxybenzoate,NADPH:oxygen oxidoreductase (3-hydroxylating), EC 1.14.13.2) has been isolated and purified from Psewdomonas aeruginosa. The reaction catalysed is linked to the pathways for degradation of aromatic compounds by microorganisms. The enzyme has been quantitatively characterized in this paper for use in the mechanistic analysis of the protein by site-directed mutagen sis. This can be achieved when the results presented are used in combination with the information on the sequence and structure of the gene for this protein and the high-resolution crystallographic data for the protein from $P$. fluorescens. The protein is a dimer of identical sub-units in solution, and has one FAD per polypeptide with a monomeric molecular weight of 45000 . A full steady-state kinetic analysis was carried out at the optimum pH (8.0). A $V_{\max }$ of $3750 \mathrm{~min}^{-1}$ at $25^{\circ} \mathrm{C}$ was calculated, and the enzyme has a concerted-substitution mechanism, involving the substrates, NADPH, oxygen, and p-hydroxybenzoate. Extensive analyses of the reactions of reduced enzyme with oxygen were carried out. The quality of the data obtained confirmed the mechanisms of these reactions as proposed earlier by the authors for the enzyme from $P$. fluorescens. It was found that the amino acid residue differences between enzyme from $P$. flucrescence and aeruginosa do marginally change some observed transient state kinetic parameters, even though the structure of the enzyme shows they have no direct role in catalysis. Thus, transient state kinetic analysis is an excellent tool to examine the role of amino acid residues in catalysis.

\section{Introducti $n$}

The monooxygenase, $p$-hydroxybenzoate hydroxylase (4-hydroxybenzoate,NADF:1:oxygen oxidoreductase, (3-hydroxylating), EC: $:$ is $\ddot{k}$, has been isolated from the Pseuoomonads, ' . _.inonas fluorescens [1], $P$. putida [2] and $P$. desmolytica [3] : "1?! recently fiuni the unrelated organism, Corynebacter.um cyclohexanicum [4]. This enzyne is linked tc the pathways for the degradation of aromatic compounds such as lignin in soils. The reaction product, protocatechuate, feeds into the $\beta$-ketoadipate pathway and can act as the sole carbon source for these organisms. This pathway has been studied extensively in $P$. putida and $P$. aeruginosa

Abbreviations: AS, amrnunium sulphate; rRNA, ribosomal RNA; pOHB, p-hydroxybenzoate; 2,4-DOHB, 2,4-dihydroxybenzoate; $\mathrm{pNH}_{2} \mathrm{~B}, p$-aminobenzuate.

Correspondence- B Entsch, Department of Biochemistry, Microbiology and Nutrition, University of New England, Armidale, N.S.W. 2351, Australia.
$[5,6]$, and the latter organism is now the model for the genetics of Pseudomonad: [7].

The hydroxylase from $P$. fluorescens has become the prototype fo: understanding the reaction mechanisms of a wide range of monooxygenases containing only flavin. as the prosthetic group [8,9]. A vigorous debate about the mechanism of the hydroxylase continues in the literature $[10,11]$, and has been further stimulated by the completion of refined structur's of the enzyme (at $1.9 \AA$ resolution [12]). It is still not clear (from the pictures of the active site) just how the protein side-chains are involved in the reaction. We decided to investigate this function by using site-directed inutagenesis.

$P$. aeruginosa was chosen as the source of the gene $f c r$ the enzyme. This organism is closely related to $P$. fluorescens, based upon the analysis of rRNA [13]. Thus, we hoped for some useful information from a comparison of protein sequences which had been subjected to limited differential selection pressure. In addition, it was sensible to relate any genetic information to the body of knowledge about $P$. aeruginosa. The complete sequence of the gene pobA from $P$. aeruginosa 
has been published [14]. The gene for the protein from $P$. fluorescens has not been studied. The protein sequence derived from the DNA sequence showed three changes compared to the protein sequence (from peptide analysis) published for the enzyme from $P$. fluorescens [15]. This is a very strong conservation of sequence even for closely related organisms. One putative change may not exist, based on the correction of the protein sequence pubished in 1986 [16] and the remaining differences are both in the domain of the enzyme that binds $p$-hydroxybenzoate. This close homology enabled the structure of the $P$. aeruginosa enzyme to be predicted by analogy to the refine structure for the enzyme from $P$. fluorescens.

As a foundation to a planned programme of site-directed mutagenesis, it was essential to establish the quantitative properties of the wild-type enzyme from $P$. aeruginosa. This paper reports an improved purification and basic properties of the enzyme from $P$. aeruginosa. It thus establishes the close similarity (implied from genetic analysis) of the protein to that from $P$. fluorescens. The oxygen reactivity has been determined in some detail, since this is the aspect of the reaction mechanism which is the target for analysis. Subtle differences in the properties of these molecules are discussed in relationship to their amino acid sequences.

\section{Materials}

The following compounds were purchased from commercial sources and then purified by recrystallization: pOHB, 2,4-DOHB. 6-hydroxynicotinate, p-aminobenzoate. Th following compounds were used as obtained from the contmercial supplier: FAD, NADPH (type III, enzymatically reduced), acrylamide and bisacrylamide, sodium dithionite and sodium azide, protein standards for molecular weight determination (for denatured and native protein analysis), and deoxyribonuclea.e I from Sigma Chemical Co; and ammonium sulphate (enzyme grade) from BDH Chemicals. Analytical gas mixtures of oxygen with nitrogen were supplied by Matheson in the U.S.A. and by C.I.G. in Australia.

The following materials for protein chromatography were used: hydroxylapatite (Bio-Gel HT) was from Bio-Rad Labs.; DEAE-cellulose (DE-52) from Whatman; Sephadex G-25, Sephacryl S-300, and Blue Sepharose from Pharmacia.

\section{Methods}

\section{Cell growth}

Enzyme was obtained from Pseudomonas aeruginosa PAO1. This strain was isolated by Holloway and has been described in great detail [7]. A sub-culture of this organism (PAO1C) was kindly supplied by Professor R.H. Olsen, University of Michigan Medical School.
Cells were stored at $-70^{\circ} \mathrm{C}$ for long periods, and were revived by plating at $25^{\circ} \mathrm{C}$ for 2 to 3 days on a minimal medium with pOHB as the source of carbon. For enzyme preparations, cells were grown by a continuous culture technique. A vessel containing 400 to $500 \mathrm{ml}$ of medium was stirred vigorously at $32^{\circ} \mathrm{C}$ and supplied with oxygen-enriched air. The culture was kept at a constant volume while medium was exchanged at $150 \mathrm{ml} \cdot \mathrm{h}^{-1}$. Analysis showed that the culture was variably limited by $\mathrm{O}_{2}$ and pOHB. The medium contaned the following chemicals in $\mathrm{g} \cdot 1^{-1}: \mathrm{NH}_{4} \mathrm{NO}_{3}(4.0)$, $\mathrm{NH}_{4} \mathrm{Cl}(1.0), \mathrm{MgSO}_{4} \cdot 7 \mathrm{H}_{2} \mathrm{O}(0.22), \mathrm{K}_{2} \mathrm{HPO}_{4}$ (3.5), and $p$-hydroxybenzoic acid $(;) ;)$. The $\mathrm{pH}$ was adjusted to 7.0 with $\mathrm{NaOH}$. Iron was supplied as the EDTA complex $\left(0.5 \mathrm{mg} \cdot \mathrm{1}^{-1}\right)$, and micronutrients were added as a standard mixture containing $\mathrm{Cu}, \mathrm{Zn}, \mathrm{Mn}, \mathrm{Ca}, \mathrm{Co}$ and Mo salts. The culture could be maintained for several days, and cells were harvested daily from a storage container at $2^{\circ} \mathrm{C}$. The yield was 7 to $8 \mathrm{~g}$ wet cells per 1 (or about $30 \mathrm{~g}$ cells per day).

\section{Enzyme assay}

The enzyme was routinely assayed spectrophotometrically as described previously [17]. Optimum rates were obtained with the following buffers: Tris-SO ${ }_{4}^{2-}$, Tricine, and Hepes (sodium salt) between 20 and $40 \mathrm{mM}$ in solution. In some steady-state kinetic analyses, the enzyme was assayed by the rate of cousumption of $\mathrm{O}_{2}$ in a Hansatech oxygen electrode vessel. Reaction conditions were the same as for the spectrophotometric assay.

\section{Purification of enzyme}

The enzyme from $P$. aeruginosa was prepared by a combination and modification of past procedures published for the enzyme from $P$. fluorescens $[18,19]$. Since the procedure is different from either published method, it is summarized below.

The method was arranged for 50 to $100 \mathrm{~g}$ wet weight of cells. Cells were thawed with 2 vol. of extraction buffer ( $50 \mathrm{mM}$ potassium phosphate, $0.5 \mathrm{mM}$ EDTA, $0.5 \mathrm{mM}$ pOHB (pH 7.0)) and $5 \mathrm{mg}$ of deoxyribonuclease was added. The suspension was sonicated ril ice with the temperature always under $16^{\circ} \mathrm{C}$ until enzyme activity reached a maximum (in about $3 \mathrm{~min}$ ). After addition of a further 2 vol. of extraction buffer, the mixture was centrifuged at $30000 \times g$ for $30 \mathrm{~min}$ at $2^{\circ} \mathrm{C}$. The supernatant was siphoned off and solid AS added to bring the solution to $43 \%$ saturation at $\mathrm{pH}$ 7.0. After equilibration to $15^{\circ} \mathrm{C}$, the mixture was centrifuged at $30000 \times \mathrm{g}$ for $20 \mathrm{~min}$ at $15^{\circ} \mathrm{C}$. Chromatography was most effective at room temperature with no loss of enzyme. The supernatant was loaded onto a column of DEAE-cellulose (bed volume, 1.5-times original cell mass) equilibrated with running buffer ( $25 \mathrm{mM}$ potassium phosphate, $1.0 \mathrm{mM}$ EDTA, pH 7.0) with $45 \%$ saturation of $\mathrm{AS}$, all at approx. $20^{\circ} \mathrm{C}$. The column was 
then washed with 2 vol. of the same solution. The enzyme fraction was then elu.ed with running buffer containing 3?\% saturation of AS. slow flow rate at elution flushed the enzyme off the column in about 2 bed volumes. Active fractions were combined and protein was precipitated by adding AS to a final concentration of $75 \%$ saturation at $\mathrm{pH}$ 7.0. The mixture was cooled to $2^{\circ} \mathrm{C}$ and centrifuged at $15000 \times \mathrm{g}$ for $10 \mathrm{~min}$ at $2^{\circ} \mathrm{C}$. The protein was redissolved in affinity buffer (10 mM Tris-maleate, $0.3 \mathrm{mM}$ EDTA ( $\mathrm{pH} 7.0$ ), volume approx. 0.5 original cell mass) and dialysed against affinity buffer at $4^{\circ} \mathrm{C}$ to remove the AS. The dialysed solution was centrifuged to remove protein precipitate, and then loaded onto a column of Blue Sepharose (bed volume about the same as the original cell mass) equilibrated with affinity buffer at about $20^{\circ} \mathrm{C}$. The column was washed with 1 vol. of affinity buffer. Protein was eluted with affinity buffer containing a gradient of $0-0.3 \mathrm{M} \mathrm{KCl}$ (about 4 bed volumes). The fractions containing enzyme were combined and loaded onto a column of hydroxyapatite (bed volume, $30-40 \%$ of the original cell mass) equilibrated with $7 \mathrm{mM}$ potassium phosphate buffer (pH 7.0) at $20^{\circ} \mathrm{C}$. The column was washed with 2 vol. of $8 \mathrm{mM}$ potassium phosphate $(\mathrm{pH}$ 7.0), then the yellow enzyme band was eluted by flushing the column with $48 \mathrm{mM}$ potassium phosphate $(\mathrm{pH}$ 7.0). Fractions containing para-hydroxybenzoate hydroxylase with an absorbance ratio for $280 / 450 \mathrm{~nm}$ of $<10$ were used for experimental purposes. The complete preparation takes 2 days if organized correctly, with yields of at least $50 \%$.

Enzyme can be stored indefinitely as a concentrated solution ( $>2 \mathrm{mg} \cdot \mathrm{ml}^{-1}$ ) in $50 \mathrm{mM}$ potassium phosphate, $0.5 \mathrm{mM}$ EDTA (pH 7.0) at $-70^{\circ} \mathrm{C}$. High purity enzyme ( $>95 \%$ protein as active enzyme) was prepared by re-cycling the fractions above thiough the affinity

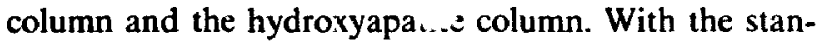
dard assay, pure enzyme has a molecular activity of
2900 to $3000 \mathrm{~min}^{-1}$, when an extinction value of 11.3 $\mathrm{mM}^{-1} \cdot \mathrm{cm}^{-1}$ is used for absorbance at $450 \mathrm{~nm}$.

\section{Protein electrophoresis}

Enzyme properties were examined in rod gels under denaturing (10\% acrylamide, sodium dodecyl sulphate) and native ( $8 \%$ acrylamide) protein conditions. Molecular weight was estimated under denaturing conditions. Procedures were taken from Chapter 1 of the laboratory manual by Hames and Rickwood [20].

\section{Transient state analyses}

The procedures used to study the catalytic pathway of the enzyme by stopped-flow spectrophotometry were described in the paper by Entsch, Ballou, and Massev concerning the mechanism of the enzyme from $P$. fiuorescens [17]. Analysis of I caction traces and calculation of rate constants and spectral species are described in Ref. 17. A further refinement of data reduction (used in this paper) was possible with the equations to solve the parameters in a reaction with three consecutive steps in such systems [21]. The equipment used was a stoppidflow spectrophotometer designed by Ballou [22] for the study of enzymes under anaerobic conditions. The spectrophotometer had a digital data recording system.

\section{Results}

\section{Purification of enzyme}

The purification procedure used was a combination and refinement of published methods for the preparation of enzyme from $P$. fluorescens, as described in Materials and Methods. Thus, with only modest amounts of cells, tile procedure was optimized to yield approx. $100 \mathrm{mg}$ of enzyme. The fate of enzyme during purification is shown in Table I. P. aeruginosa produced a high level of enzyme when growing on pOHB

\section{TABLE I}

Purification of enzyme

A total of 60-62 g (wet wt.) of packed cells were accumulated from continuous culture over 2.5 ays. Ce.ts were snap frozen in liquid nitrogen and stored at $-70^{\circ} \mathrm{C}$ before extraction. Purification was carried out as described in Methods.

\begin{tabular}{|c|c|c|c|c|c|c|}
\hline Stage in purification & $\begin{array}{l}\text { Volume } \\
\text { (ml) }\end{array}$ & $\begin{array}{l}\text { Protein } \\
\text { (mg) }\end{array}$ & $\begin{array}{l}\text { Activity } \\
\text { (units) }\end{array}$ & $\begin{array}{l}\text { Spec. Act. } \\
\text { (units } \cdot \mathrm{mg}^{-1} \text { ) }\end{array}$ & $\begin{array}{l}\text { Recovery } \\
\text { (\%) }\end{array}$ & $\begin{array}{l}\text { Purification } \\
\text { (-fold) }\end{array}$ \\
\hline Supernatant from sonication & 286 & 4720 & $7970^{2}$ & 1.7 & 100 & $\overline{1}$ \\
\hline Supernatant from $43 \%$ AS & 315 & 2760 & 7220 & 2.6 & 90 & 1.55 \\
\hline After dialysis & 55 & 840 & 5500 & 6.55 & 69 & 3.9 \\
\hline Eluate from Blue Sepharose & 54.5 & 172 & 5040 & 29 & 63 & 17 \\
\hline Eluate from hydroxyapatite & 31 & 98 & 4800 & $49^{h}$ & 60 & $29^{b}$ \\
\hline
\end{tabular}

This value translated to enzyme approx. $1.5 \%$ of total cell protein.

b At these values, the enzyme was $80 \%$ of the protein preseni. Pure enzyme has a specific activity of 62 to 63 (based on flavin content and molecular weight). Pure enzyme was obtained by cycling tha product through the last two steps of the purification. with collection of peak fractions. 
as carbon source (apprex. $1.5 \%$ by weight of the total cellular protein). At the end of the purification shown in the Table, the enzyme was $80 \%$ of the total protein present (the remaining $20 \%$ was other proteins). The preparation was stable and suitable for most experimental work (there were no other components that interfered with measurement of the flavin of the enzyme). When needed, pure enzyme was obtained by recycling a sample of the preparation through the last two steps in the regular procedure (see Table I), with careful selection of only the cleanest enzyme fractions.

With handling and use, the enzyme preparation developed inactive forms, based on the specific activity per unit flavin present. This material could be returned to a fully active sample by passage through a small column of hydroxyapatite, as used in the last step in the purification procedure.

\section{Molecular properties}

The enzyme was subjected to electrophoresis under denaturing conditions in polyacrylamide gels, and its mobility was compared to both the same enzyme from $P$. fluorescens, and to molecular weight standards. Since the enzyme samples had the same mobility within experimental error, the unknown had a single polypeptide with an estimated molecular weight of 45000 . The exact molecular weight of the polypeptide from $P$. fluorescens is 44320 , as obtained from the amino acid sequence [15]. The molecular weight of the polypeptide from $P$. aeruginosa, as calculated from the nucleotide sequence [14], is 44,324 . When electrophoresis was carried out under non-denaturing conditions, the enzyme slowly lost the flavin cofactor (which migrates faster). The apoprotein gradually precipitated in the gel, as shown by the smear of protein down the gel upor: staining.

The flavin cofactor was found to be FAD, after analysis of the protein-free cofactor by HPLC [23]. An estimation was made of the dissociation constant for the flavin-protein complex. Concentrated enzyme solution was diluted to $2.0 \cdot 10^{-8} \mathrm{M}$ at $\mathrm{pH} 8.0$ and $25^{\circ} \mathrm{C}$ with standard assay buffer. It was assayed at this concentration by the addition of a mixture of pOHB and NADPH. The activity of samples was measured at times from the moment of dilution until an apparent equilibrium was reached (after about $5 \mathrm{~min}$ ). An estimate was made of the dissociation constant based on the assumption that the rate of association and dissociation of FAD with enzyme was slow compared to the time required to measure the catalytic activity of holo-enzyme. Under the conditions of the experiment, enzyme regained full activity upon addition of a large excess of FAD. A value of 5 to $6 \cdot 10^{-9} \mathrm{M}$ was obtained for the apparent dissociation constant. Müller and Van Berkel [24] obtained an apparent constant of $4 \cdot 10^{-8} \mathrm{M}$ for enzyme from $P$. fluorescens. However, they used separate preparations of apoprotein and FAD, and had $0.1 \mathrm{M}$ phosphate and pOHB in the incubation solution. The enzyme specifically uses NADPH rather than NADH as electron donor substrate for the reduction of oxygen to the peroxide level.

The pure enzyme is stable at $40^{\circ} \mathrm{C}(\mathrm{pH} 8.0)$, but has a measurable rate of denaturation at $50^{\circ} \mathrm{C}$ over $30 \mathrm{~mm}$. The rate of decomposition at $50^{\circ} \mathrm{C}$ was slower in the presence of pOHB. The enzyme was also stable at $25^{\circ} \mathrm{C}$ over a pH range of 5.5 to 8.5. Slow denaturation was observed at pH 4.5 and 9. These observations are in agreement with the comprehensive new data published for the effects of temperature on the enzyme from $P$. fluorescens [25].

The behaviour of the enzyme in solution was examined by chromatography on a column of Sephacryl S-300, with a running buffer of $0.2 \mathrm{M} \mathrm{Na}_{2} \mathrm{SO}_{4}, 50 \mathrm{mM}$ phosphate as the potassium salt, and $0.5 \mathrm{mM}$ EDTA (pH 7.0). These conditions were necessary to maintain the native enzyme mostly intact, and to compare behaviour with that of the enzyme from $P$. fluorescens [19]. At $23^{\circ} \mathrm{C}$, both enzymes behaved in a similar manner. Most of the enzyme eluted as a single peak, but the enzyme from $\boldsymbol{P}$. fluorescens had a secondary peak in front of the main peak, as described by Müller and co-workers [19]. The molecular weight of the molecule from $P$. aeruginosa was estimated by reference to standard proteins to be $75000 \pm 5000$ (well above the monomeric molecular weight). The published value for enzyme from $P$. fluorescens is $79000 \pm 3000$ [19]. New work just published for the protein from $P$. fluorescens [26] has established that the principal peak eluted from Sephacryl S-300 is the dimer seen in the crystallographic structure. The low molecular weight estimate may be due to the elongated shape of the dimer. Smaller enzyme peaks eluted before the dimer are due to larger aggregates of the polypeptide - due to chemical changes at Cys-116 after isolation. Thus, it is likely that the enzyme from $P$. aeruginosa is also a stable dimer in solution, based on the results with Serhacryl.

\section{Steady-state kinetics}

The properties of the enzyme under study are very close to the extensively analysed enzyme from $P$. fluorescens. The enzyme required an aromatic substrate or analogue to stimulate the oxidation of NADPH. Turnover rates from assays (at $\mathrm{pH} 7.1,25^{\circ} \mathrm{C}$ ) with pOHB, 2,4-DOHB, $\mathrm{pNH}_{2} \mathrm{E}$, and 2-hydroxypicolinate were almost identical to those measured for the $P$. fluorescens enzyme. The optimum $\mathrm{pH}$ for turnover with pOHB was 8.0 to 8.1 , with Hepes or $\mathrm{Tris}^{-\mathrm{SO}_{4}^{2-}}$ as buffer (with a broad maximum).

The dependence of the reaction on natural substrate conce.ntrations was studied at $\mathrm{pH}$ 8.0, with systematic variation of the concentrations of pOHB, NADPH, and oxyger. The pattern of reciprocal piots obtained for velocity against substrate concentration was qualita- 


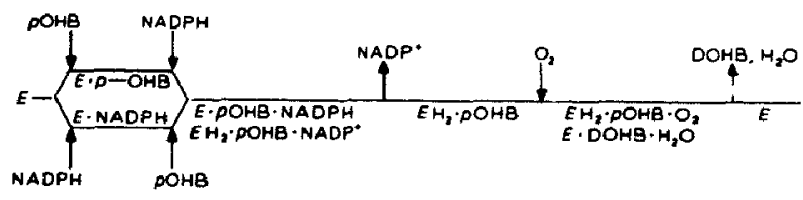

Scheme !.

tively identical to that published for the enzyme from $P$. fluorescens $[27,28]$. This established that the reaction pathway is the same for both enzymes. In the terminology of Dalziel [29], the enzyme has a 'concerted-substitution mechanism' illustrated by the reaction pathway in Scheme $I$.

The basic features of the mechanism are first the formation of a ternary enzyme complex with NADPH and pOHB. After this, the FAD of the enzyme is reduced by NADPH, and the NADP ${ }^{+}$is released from the enzyme. The reduced enzyme in complex with pOHB then reacts with oxygen, followed by liberation of product, 3,4dihydroxybenzoate, and return of the original form of the enzyme. The parameters obtained for each substrate from the reciprocal plots are shown in Table II. The values represent the optimum parameters for the enzyme at $25^{\circ} \mathrm{C}$. Previous analyses of substrate kinetics for any preparation of $p$-hydroxybenzoate hydroxylase have not been under optimum conditions. The results recorded in Table II yield a calculated $V_{\max }$ of 3750 $\min ^{-1}$.

\section{Oxygen reactivity (transient state analyses)}

Detailed accounts of oxygen reactions with the enzyme from $P$. fluorescens (using transient state analyses) have been published previously $[17,30,10]$. An im-

\section{TABLE II}

Steady-state kinetic Darameters for enzyme with pOHB as substrate

Parameters for the equation below were calculated from intercepts and slopes of secondary plots of initial rate data treated as described by Dalziel [29] for a three-substrate reaction, and specifically for p-hydroxybenzoate hydroxylase by Husain and Massey [28]. The values apply to optimum conditions for the enzyme ( $33 \mathrm{mM}$ Tris as the $\mathrm{SO}_{4}^{2-}$ salt, $0.5 \mathrm{mM}$ EDTA (pH 8.0) at $25^{\circ} \mathrm{C}$ )

$\phi: \frac{e}{v_{0}} \phi_{0}+\frac{\phi_{\mathrm{pOHB}}}{[\mathrm{pOHB}]}+\frac{\phi_{\mathrm{NADPH}}}{[\mathrm{NADPH}]}+\frac{\phi \mathrm{O}_{2}}{\left[\mathrm{O}_{2}\right]}+\frac{\phi_{\mathrm{pOHB}} \cdot \mathrm{NADPH}}{[\mathrm{pOHB}] \cdot[\mathrm{NADPH}]}$

\begin{tabular}{|c|c|c|c|}
\hline $\begin{array}{l}\text { Coefficient in } \\
\text { equation }\end{array}$ & $\begin{array}{l}\text { Measured } \\
\text { value }\end{array}$ & Substrate & $\begin{array}{l}\text { Michaelis } \\
\text { constant }\end{array}$ \\
\hline $\begin{array}{l}\phi_{0} \\
\phi_{\text {pOHB }} \\
\phi_{\mathrm{NADPH}} \\
\phi_{\mathrm{O}_{2}} \\
\phi_{\mathrm{pOHB} \cdot \mathrm{NADPH}}\end{array}$ & $\begin{array}{l}2.67 \cdot 10^{-4} \mathrm{~min} \\
2.90 \cdot 10^{-9} \mathrm{M} \cdot \min \\
6.2 \cdot 10^{-9} \mathrm{M} \cdot \min \\
9.9 \cdot 10^{-9} \mathrm{M} \cdot \min \\
1.45 \cdot 10^{-13} \mathrm{M}^{2} \cdot \min \end{array}$ & $\begin{array}{l}- \\
\text { pOHB } \\
\mathrm{NADPH} \\
\mathrm{O}_{2} \\
-\end{array}$ & $\begin{array}{l}- \\
1.09 \cdot 10^{-5} \mathrm{M} \\
2.32 \cdot 10^{-5} \mathrm{M} \\
3.71 \cdot 10^{-5} \mathrm{M} \\
-\end{array}$ \\
\hline
\end{tabular}

portant practical consideration was the early demonstration that hydroxylation of substrare occurs when oxygen reacts with a complex of reduced (FADH ${ }^{-}$) enzyme and $\mathrm{POHB}$ which has remarkable kinetic stability [17]. The effective procedure for study is to isolate the oxygen reactions of the catalytic cycle from the reductive segment. This has been accomplished by reducing the enzyme flavin stoichiometrically with sodium dittionite before reaction of the substrate complex with oxygen. The reaction is monitored by stopped-flow spectrophotometry over a range of wavelengths suitable to characterise the FAD, and in some cases, the substrate. The vast majority of studies of this reaction have been carried out at $\mathrm{pH} 6.55$ and 2 to $4^{\circ} \mathrm{C}$. These conditions were found to be optimum for the detection and analysis of the transient phases of the reaction. The original conclusions about the mechanism of the reaction from stopped-flow spectrophotometry [17] have been largely confirmed in many subsequent studies (see review by Ballou [8]).

If the enzyme from $P$. aeruginosa was to be used for genetic/structural analyses, then it was essential to compare its transient state kinetic behaviour quantitatively with the enzyme from $P$. fluorescens under the same conditions. Amino acid substitutions in the protein could change the kinetic parameters of catalysis in unexpected ways. In this study, we chose to examine the reactions with the natural substrate (pOHB), with 6-hydroxynicotinate (known to stimulate turnover without product formation), and with 2,4-DOHB (a substrate which emphasizes the transient states in the catalytic process).

Upon mixing the reduced substrate-free enzyme with oxygen, the flavin changed from the reduced spectrum to the oxidised spectrum in a single, pseudo-first-order reaction. Oxygen dependence of this monophasic reaction showed that it was a reversible second-order process. The rate constant measured for this reaction is recorded in Table III with the same measurement for the enzyme from $P$. fluorescens. There was no stabilization of an oxygenated flavin in the reaction as there is in the presence of substrate. It is now known that there are many differences in the active site arrangement of amino acid groups in the presence and absence of substrate [31]. The reaction product was $\mathrm{H}_{2} \mathrm{O}_{2}$ by analogy with earlier results with this enzyme.

In the next series of experiments, the enzyme was reduced with dithionite as above, and then mixed with 6-hydroxynicotinate. The binding of this substrate analogue to the enzyme was followed at $375 \mathrm{~nm}$. The cbserved rate of association was $53 \mathrm{M}^{-1} \cdot \mathrm{s}^{-1}$ at $2^{\circ} \mathrm{C}$. The dissociation constant was determined from the equilibrium changes in absorbance with different concentrations of hydroxynicotinate $-K_{\mathrm{d}} 1.6 \cdot 10^{-4} \mathrm{M}$ at $2^{\circ} \mathrm{C}$. Thus, the dissociation rate constant was calculated to be $8.5 \cdot 10^{-3} \mathrm{~s}^{-1}$. These rates of exchange are so slow 
TABLE III

Summary of rate constants in oxygen reachons from transient state analyses

Reactions were carried out as outlined in Methods and Results. Final solutions contained $50 \mathrm{mM}$ phosphate as the potassium salt, $1 \mathrm{mM}$ EDTA (pH 6.55). Each substrate ot analogue was present in sufficient concentration to saturate the active site of reduced enzyme. Reactions were initiated by the mixture of reduced enzyme with oxygenated buffer in the stopped-fiow apparatus. Temrerature was slightly different with each reaction and is listed for each set of rate constants. Results obtained in the past for enzyme from $P$. fluorescens [17] are presented in parentheses. Each rate constant in the body of the table is the mean of multiple measurements taken under the conditions of each rcaction. The relative error in all cases is such that the true values should be within $\pm 5 \%$ of the mean (greater than two standard deviations).

\begin{tabular}{lll}
\hline $\begin{array}{l}\text { Temperature } \\
\left({ }^{\circ} \mathrm{C}\right)\end{array}$ & $\mathrm{M}^{-1} \cdot \mathrm{s}^{-1}$ & Reactions and rate constants \\
\hline & & $\mathrm{s}^{+1}$
\end{tabular}

$2.56 \cdot 10^{4}$
$\left(2.55 \cdot 10^{4}\right)$

1.8

(50)

20

(3.5)

3.5

(3.5)
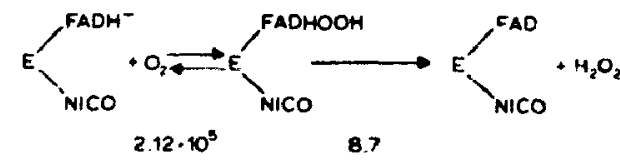

$\left(1.82 \cdot 10^{5}\right) \quad(10.7)$

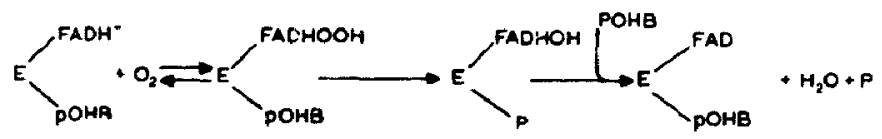

$2.73 \cdot 10^{3} \quad 45$

(48)

13.9

(14.5)

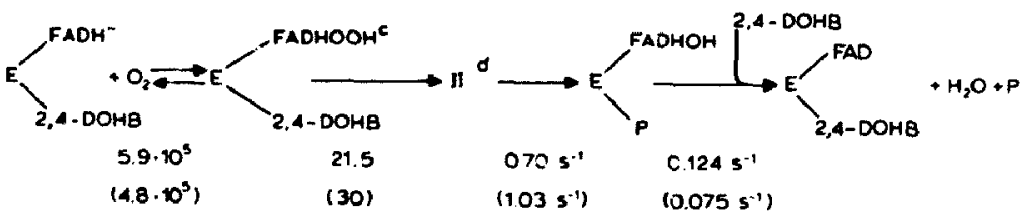

- The primary interaction with oxygen is thought to be formation of a radical pair [8]. This may be a reversible, second-order reaction which occurs in all reactions in this column, but has been left out for convenience.

b The formation of a peroxynavin is implied in this reaction, and was not detected because the rate constant for decay was larger than the preceding rate constants. This intermediate has been detected on the reaction path under special conditions [17].

c When 2,4-DOHB was the substrate used, the peroxyflavin decayed by two divergent paths. One fraction (76\%) formed hydroxylated product, and the remainder (24\%) formed $\mathrm{H}_{2} \mathrm{O}_{2}$ and no product. Similar observations have been made with the enzyme from $P$. fluorescens [17].

d The symbol II is used to refer to the high absorption intermediate (see Fig. 4), which may be a free radical pair between flavin and oxygenated substrate [33].

Special abbreviations used in this Table: Nico, 6-hydroxynicotinate; E, enzyme; P, product (oxygenated substrate).

that the analogue could not exchange with the reduced enzyme in normal catalysis. This observation confirms the kinetic stabilization of the complexes of reduced enzyme with substrate, which has been examined in detail for the enzyme from $P$. fluorescens [17]. The physical explanation for this slow binding phenomenon remains elusive. The $\mathbf{X}$-ray crystallographic data provided by Schreuder [12] show no apparent difference in the aciive site of the enzyme between oxidised and reduced enzyme complexes. However, the rate constant for binding to oxidised enzyme is a factor of $10^{5}$ greater than that for binding to the reduced enzyme.
The reduced enzyme in complex with 6-hydroxynicotinate was reacted with oxygen (note that this compound was not hydroxylated by the enzyme). The reaction was biphasic. The first phase was oxygen dependent, $t$ and the second phase was not. The rate constants measured for these reactions are recorded in Table III. The dependence of the reactions on wavelength was analysed to calculate the true spectrum of the transient flavin species defined by these consecutive reactions, and recorded in Fig. 1. This pattern is analogous to the reaction of the enzyme from $P$. fluorescens, and the intermediate species must be the flavin $\mathrm{C}-4 \mathrm{a}$ hydro- 
peroxide. The stability of the putative hydroperoxide is influenced by pH in this complex - ai higher $\mathrm{pH}(9.0)$, the peroxide decomposes much more rapidly, and is barely detectable in the reaction.

The next stage in analysis was to follow the reaction of reduced enzyme with oxygen when the natural substrate was hydroxylated. In this case, the absorbance changes were readily interpreted as representing three consecutive reactions. The first reaction in time was like those in the preceding cases - oxygen dependent. This dependence upon oxygen was studied over the widest concentration range experimentally possible (see Fig. 2). There was a clear linear relationship between observed rate and oxygen concentration, with the line of best fit showing a finite intercept on the $\boldsymbol{Y}$-axis (Fig. 2). This result is consistent witl. a second-order reversible reaction with oxygen to form a complex [32]. This complex is experimentally identical with the first observed transient chemical species (the flavin C-4a hydroperoxide). The slope of the line in Fig. 2 is a measure of the second-order rate constant in the forward direction, and its magnitude is recorded with other rate constants

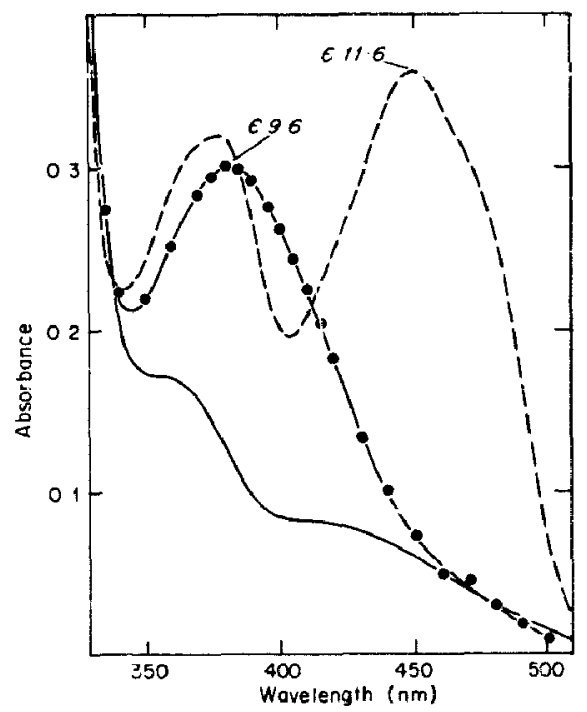

Fig. 1. Absorption spectra of flavin species detected when reduced enzyme in complex with 6-hydroxynicotinate was reacted with oxygen. The solid curve represents the absorbance of reduced enzyme in complex with nicotinate, and the dashed curve is the absorbance of oxidised enzyme in complex with nicotinate (spectrophotometer recordings). The points marked ( $\bullet$ ) which outline the third spectrum (a transient flavin species in the reaction), represent calculated absorbances obtained from analysis of reactions at each marked wavelength, as described in Methods and Results. This spectrum (absorbance maximum $382 \mathrm{~nm}$ ) is characteristic of the flavin C-4a hydroperoxide as shown in the reaction path recorded in Table III (nicotinate was not hydroxylated). Extinction values $(\varepsilon)$ for key absorption maxima are shown on the figure. The final reaction solution in the stopped-flow spectrophotometer (path length, $2 \mathrm{~cm}$ ) contained $15.5 \mu \mathrm{M}$ enzyme, $0.65 \mathrm{mM}$ oxygen, $5.0 \mathrm{mM}$ 6-hydroxynicotinate, $50 \mathrm{mM}$ fhosphate (potassium salt), and $6.0 \mathrm{mM}$ EDTA (sodium salt) (pH 6.55) at $1.8^{\circ} \mathrm{C}$.

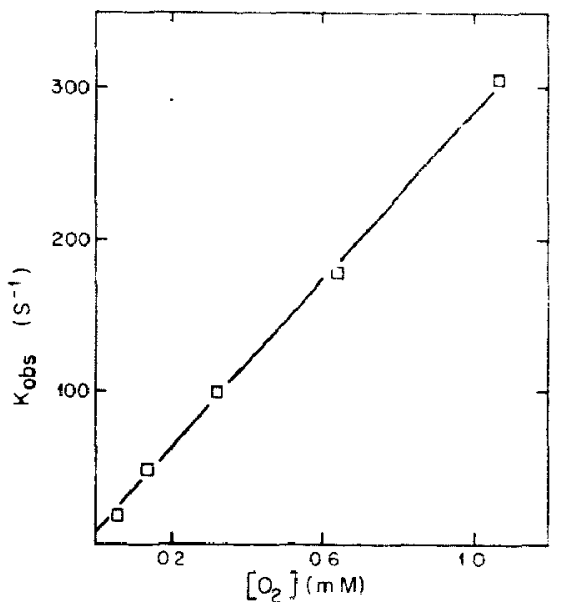

Fig. 2. The dependence on oxygen concentration of the rate of formation of flavin C-4a hydroperoxide in the complex of enzyme with pOHB. Reduced enzyme in complex with the substrate was reacted with the concentrations of oxygen shown in the stopped-flow spectrophotometer. The reaction was monitored in isolation at 388 $\mathrm{nm}$, an isosbestic point for the hydroperoxide, the hydroxide, and oxidised enzyme (see Fig. 3). Each point on the diagram represents the mean of several reactions, and the standard deviation in each case was no larger than the experimental points ( $\square$ ). The final reaction solution in the spectrophotometer (path length, $2 \mathrm{~cm}$ ) contained 12.6 $\mu M$ enzyme, variable oxygen. $0.75 \mathrm{mM}$ pOHB, $50 \mathrm{mM}$ phosphate (potassium salt), and $1.0 \mathrm{mM}$ EDTA $(\mathrm{pH} 6.55)$ at $2.0^{\circ} \mathrm{C}$.

in Table III. Chemical studies have suggested that there may be a free radical pair [8] as a compulsory intermediate in the formation of the peroxide (as represented in the top of Table III), but there is no kinetic evidence for this in the data available.

The consequence of three observed consecutive reactions involving the flavin is the presence of two detectable transient chemical species. A complete analysis of the changes over a range of wavelengths led to the calculation of two transient spectra (Fig. 3). These species can now be identified by analogy to the reactions of the enzyme from $P$. fluorescens as the flavin C-4a hydroperoxide and hydroxide (the latter formed from the former after tansfer of one atom of oxygen to the substrate). The formation of the hydroxide from the peroxide involves a distinctive shift in the observed absorption band from a maximum at 390 to $380 \mathrm{~nm}$ (Fig. 3). This is consistent with measurements of chemical models [8]. There is no contribution to the absorption spectra shown by either substrate or product, which only start to absorb below $320 \mathrm{~nm}$. The flavin C-4a hydroxide then decays to the final spectrum - oxidi .ed flavin in complex with pOHB. The reaction is summarized with the measured rate constants in Table III.

The final set of oxygen reactions reported in this paper involve the transient states observed when the enzyme is complexed with an alternate substrate, 2,4DOHB. In the reaction with the enzyme from $P$. fluor- 
escens, three transient chemical species were clearly defined by the kinetics. The first and third species detected have been equated with the flavin C-4a hydroperoxide and $\mathrm{C}-4 \mathrm{a}$ hydroxide as described above for the reaction with natural substrate, pOHB. The second transient, called intermediate II in the past [17], has been difficult to identify. The best evidence currently available suggests that it represents a free radical pair between oxygenated flavin and oxygen-substituted substrate $[11,33]$. That is, an oxygenated substrate radical intermediate makes a contribution to the observed spectrum. The reactions with the enzyme from $P$. aeruginosa were qualitatively the same as earlier work, but the istal analysis of the kinetic traces (see Table III) showed small, but significant quantitative differences in rate constants. The transient species calculated from the wavelength dependence of the reactions (Fig. 4) were similar to earlier published observations. However, the spectra have been calculated and presented for one set of reaction conditions in Fig. 4. Earlier results for the reactions with $\boldsymbol{P}$. fluorescens enzyme have come from a series of reaction conditions. Again, small, but significant quantitative differences were detected in the spectra. It should be noted that the first transient (the flavin C-4a hydroperoxide) could not be calculated accuratelv

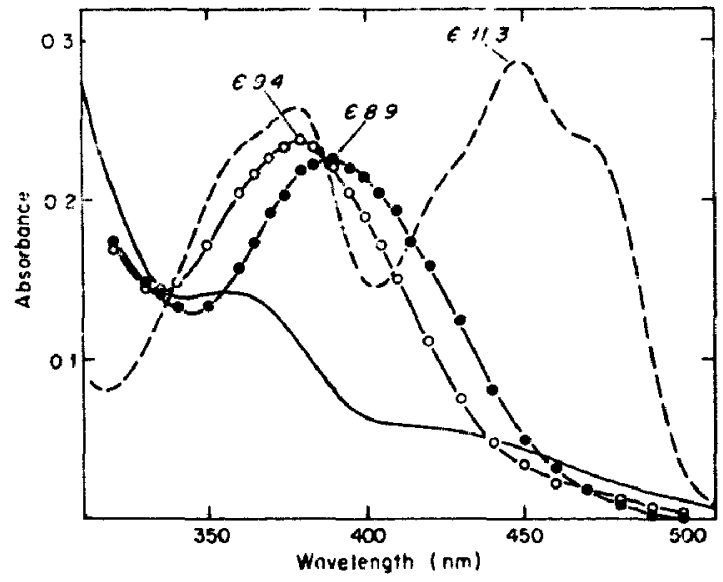

Fig. 3. Absorption spectra of flavin species detected when reduced enzyme in complex with pOHB was reacted with oxygen. The solid curve represents reduced enzyme, and the dashed line represents oxidised enzyme, both in complex with pOHB (spectrophotometer recordings). The points marked $(0)$ and $(0)$ outline the spectra of the transient chemical species detected in the reaction. Points represent experimentally calculated absorbances of the transient species obtained from analyses of reactions at each marked wavelength, as described in Methods and Resulis. The spectrum represented by points - (absorbance maximum $390 \mathrm{~nm}$ ) is characteristic of the flavin $\mathrm{C}-4 \mathrm{a}$ hydroperoxide, and the subsequent spectrum formed, $O$ (absorbance maximum $380 \mathrm{~nm}$ ) is characteristic of the flavin C-4a hydroxide. The reaction path (which includes the hydroxylation of pOHB) is summarized in Table III, and extinction values ( $\varepsilon$ ) for key absorption maxima are shown on the figure. The final reaction solution in the stopped-flow spectrophotometer is the same as in the legend to Fig. 2, with $1.07 \mathrm{mM}$ oxygen.

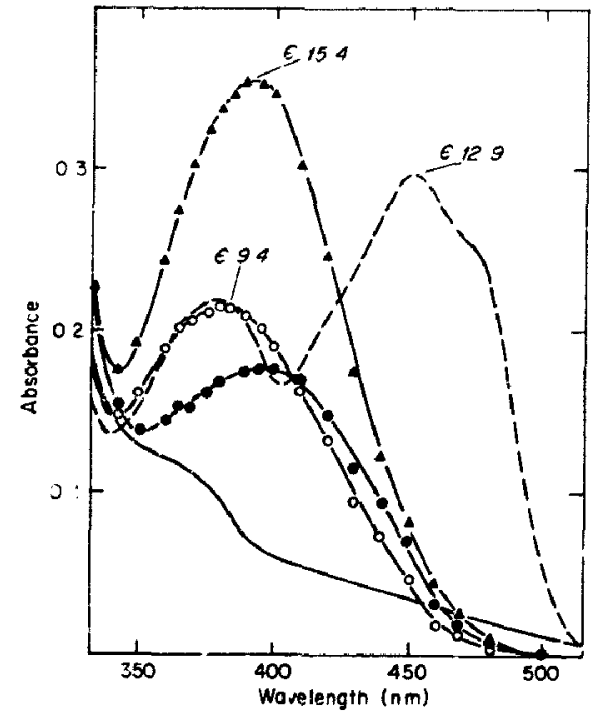

Fig. 4. Absorption spectra of chemical species detected when reduced enzyme in complex with 2,4-DOHB was reacted with oxygen. The solid curve represents reduced enzyme, and the dashed line represents oxidised enzyme, both in complex with 2,4-DOHB. Note thai substrate binding induces changes in the quantitative parameters of the spectrum of enzyme-bound flavin (compare the spectra in this Figure with Figs. 1 and 3 ). The points marked (. .4 . and 0 ) cutline the spectra of the transient chemical species detected in this reaction. Points represent experimentally calculated absorbances obtained from analyses of reactions at each marked wavelength, as described in Methods and Results. Points (o) approximately represent the first intermediate formed (flavin C-4a hydroperoxide), and points (O) represent the last intermediate formed, the flavin $\mathrm{C}-4 \mathrm{a}$ hydroxide (absorbance maximum $382 \mathrm{~nm}$ ). Note the similarity of these transient species to thise for the pOHB reaction illustrated in Fig. 3. The points (a) describe the high extinction intermediate formed (absorbance maximum $391 \mathrm{~nm}$ ) upon oxygen transfer to 2,4-DOHB (labelled II in Table III). This intermediate may consist of a flavin C-4a derivative plus a cuntribution from a íree radical intermediate in product formation [33]. The reaction path is summarized in Table III, and extinction values $(\varepsilon)$ for prominent absorption maxima are shown on the figure. The final reaction solution in the stopped-flow spectrophotometer (path length, $2 \mathrm{~mm}$ ) contained $12.6 \mu \mathrm{M}$ enzyme, $0.65 \mathrm{mM}$ oxygen, $2.5 \mathrm{mM}$ 2,4-DOHB, $50 \mathrm{mM}$ phosphate (potassium salt), and $1.0 \mathrm{mM}$ EDTA (pH 6.55) at $35^{\circ} \mathrm{C}$.

from the experimental data, since the combination of amplitudes and rate constants did not permit full kinetic isolation of the events. An approximation to the spectrum was obtained by plotting the spectrum of the solution at a time $6 \mathrm{~ms}$ after the reaction commenced. This should be approx. 4 half-lives along the reaction to form the intermediate. Thus, the spectrum ( $\bullet$ ) in Fig. 4 should represent at least $90 \%$ of the enzyme as the flavin hydroperoxide.

The oxygen reactions with 2,4-DOHB were also car-

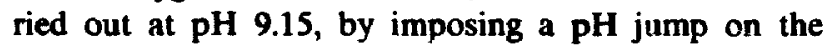
reaction from the oxygenated buffer component in the stopped-flow spectrophotometer. This was done to exarnine the spectrum of intermediate II at the higher $\mathrm{pH}$. Just as has been documented for the $P$. fluorescens 
enzyme [34], the spectrum had changed substantiaiiy, with the observation of a broader band with a maximum absorption at longer wavelength (Data not shown).

\section{Discussion}

The results presented in this paper provide a foundation of information for future studies of modified forms of the enzyme produced from the pobA gene from $P$. aeruginosa. It is a considerable advantage for mutagenesis studies that this enzyme can be produced in its normal molecular structure in Escherichia coli (Entsch, B., unpublished observation). Clearly, because of sequence homology and molecular and kinetic similarities reported in this paper, much of the detailed information available in the literature for the enzyme from $P$. $f l u$ orescence can be applied to the protein under study here. However, there is also some useful new information about the enzyme in this paper. The estimations of the apparent dissociation constants for the combination of FAD and apoprotein $\left(5 \cdot 10^{-9} \mathrm{M}\right.$ in this study and $4 \cdot 10^{-8} \mathrm{M}$ by Müller and Van Berkel [24]) are surprisingly high, given the large number of interactions between these molecules, as shown by the crystal structure [15]. The explanation for this relatively weak binding may come from the results of the high resolution picture of the enzyme recently published [12]. The oxidised state of the flavin ring is apparently held in a slightly twisted (and strained) configuration in the enzyme active site which is probably arranged to preferentially stabilize the oxygenated (non-planar) flavin intermediate. Thus, some of the potential binding energy for FAD to enzyme may be used in promoting catalysis; a general concept explained by Fersht [35].

The steady-state kinetic interactions between enzyme and substrates at standard temperature and optirnum $\mathrm{pH}\left(25^{\circ} \mathrm{C}\right.$ and $\left.\mathrm{pH} 8.0\right)$ have not been reported before. The results presented show a theoretical maximum velocity of $3750 \mathrm{~min}^{-1}$. This value is substantially higher than any result reported previously for this enzyme from any source. Earlier values reported were not obtained at the $\mathrm{pH}$ optimum, enzyme was not saturated with all substrates, or involved the use of solvent conditions which were partially inhibitory. This turnover number should be close to, if not identical to the value for the enzyme from $P$. fluorescens (value unknown). Based on earlier studies of the $\boldsymbol{P}$. fluorescens enzyme, the rate determining step at $\mathrm{pH} 8.0$ is probably the dissociation of NADP $^{+}$from the reduced form of the enzyme [1].

When the work reported in this paper commenced, there was no knowledge of the degree of homology between the structures of the enzymes from $P$. fluorescens and aeruginosa. As work progressed, the detailed genetic information [14] became complete, and established that the molecules were very close in amino acid sequence. The consequences were clear. All the structural information about the enzyme from $P$. fluorescens could be translated with confidence to the molecule from $P$. aeruginosa. Thus, the gene pobA from aeruginosa was a perfect tool for directed mutagenesis. However, it was necessary to show that the cutalytic process was identical.

There are two established differences in the sequences as measured. The information for $P$. fluorescens comes from direct measurement of amino acid sequence [15], while that for $P$. aeruginosa comes from the DNA sequence of pobA. This discussion treats the sequence from $P$. fluorescens enzyme as the baseline. The first difference is position 228 (Thr to Ser change). This residue is in a loop between $\beta$-sheet B6 and $\alpha$-helix $\mathrm{H} 8$ in the substrate-binding domain of the protein, where its side-chain probably points into the cavity involved in the binding of substrate (based on the refined, high-resolution structure recently published by Schreuder [12]). However, this residue is not within contact distance with the bound substrate. The second difference is position 249 (Ala to Ser change). This residue is the first amino acid of helix $\mathbf{H 9}$, which is a small structure at the surface of the protein in the substrate domain. The residue is in contact with solvent, and the substitution does not significantly change the packing of the protein (Drenth, J., personal communication).

Could such small changes have any secondary affects on catalysis? The interesting conclusion is yes. It is clear that large effects, caused by changes in enzyme contacts in the active site, cannot occur. However, an interesting result was detected in the interactions of enzyme with 2,4-DOHB. Some rate constants measured for the oxygen reactions with this substrate were different in magnitude from those for the reactions measured for the $\boldsymbol{P}$. fluorescens enzyme (see Table III). The slowest reaction does result in a faster turnover by the enzyme molecule under study, as it is the rate determining step. The $K_{d}$ for oxidised enzyme with substrate is 4-fold smaller for $P$. aeruginosa enzyme under the same conditicns. That is, 2,4-DOHB binds more tightly. There seems to be a clear lesson from this work for protein engineering. An amino acid residue can only be considered essential to catalysis by an enzyme if no structural modification is caused unon its aliciation to another residue, but the change causes major disruption to the normal reaction path. Unrelated residues can cause minor changes, as found in this work.

Change in surface polarity of a protein can have dramatic and unexpected results, as the case of the relationship between hemoglobin and sickle-cell anemia illustrates [36]. It is possible that the hydroxyl group of Ser-249 of the $P$. aeruginosa enzyme (compared to Ala-249 of the fluorescens enzyme) influences the solution behavior of the protein. Careful studies by Müller's group in Holland showed that the $P$. fluorescens enzyme 
forms dinuerh and also higher order gisoviations of molexules in solution [10]. It has now heen establishad that stable higher molecular weight species arise from the oxidative coupling of Cys- 116 between dianers at the surface of the protein [26]. Our results again provide evidence for timets with the $P$, aruginoso enzyme, but we did not observe higher order interactions under conditions which showed this phenomenon with the $P$. fluorescens enzyme. This seems to be a teasonable consequence of the anino acis substitution. Residuc 2.19 is lat removed from the sutface portion of the proirin responsible for the forcration of dimcr, but provides extra polarity to the surface of the molecule from $P$. aengimasa, which may inhibit higher order assoctations of the protein which result in covalent soupling under some conditions.

\section{Acknowledgements}

We thank Arntelle Bucchiella for valuable technica! essistance, and Professor R.H. Olsen for supplying us with Psetedominas aeruinosa PAO1C. This work was supported in part by the Australian Research Grants Scheme, and in part by the U.S. National Institules of Health.

\section{References}

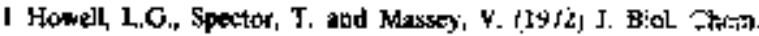
$247,4340-4350$.

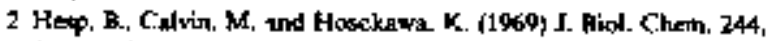
$5644-5655$.

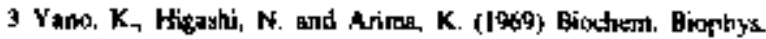
Res. Commun 34, 1-?

4 Fujii, T. and Kaneda, T. (J夗S) Eur. J. Bicchen. 147, 9T-164.

3 Singier, R.Y, and Omaton, L.N. (4973) Adv. Microb. Physiol 9 $\$ 9-151$.

6 Ombkri. L.N. and Parke, D. \{i9\}7\} Curs. Top. Cell Regul. 12, $209-262$.

7 Holloway. 8.W', and Morgan. A.F. (!986) Annu. Rev, Mitrobiol. 4), $29-105$.

8 Ballos. D.P. (1984) in Flavins hard Flavogrcteins (Bray, R.C.. Eigy, P.C. and Sayhew, S.0., edk.), pp. 605-61s, Walter de Gruyler, Berin.

9 Muller, F, (1985) Biochern Sce. Trans 13, 443-447.

10 Entsen, B., Massey, S. and Claiborre, A. (1987) I. Biol. C.twen 262 , thax $60-6068$.

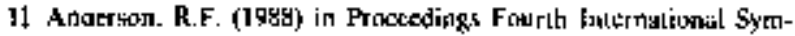
posium on Oxidases and Related Redok Systems [Mason. H.S. ed.'t, Alun R, Li5s, Now York. in press.

12 Schreader, H.A. (I9g9) Doctoral Dissettution. Uniuersity of Groningen, Nerherlands.

13 Woese, C.R. (1987) Micuabiol. Rer. \$1, 221-27t.

14 Entsch, B., Yang Nan, Weaich, K. and Scont. K.F. (1989) Gene 71, $279-291$

15 Wejet, W.J., Holstenge. J., Beinterna, J.J., Wicrenga, R.K. and Dret1h, J. (1963) Eur, J. Biochem. 133, 109-118

16 Wijnands, R.A., Wejer, W.J., Mlilke, F.. Jekel, F.A., Van Berke1, W.J.H. and E-intema, J.J. (1986) Bixchemişury 25, 4211-4z1k.

17 Entseb, B., Ballow, D.P. and Massey, V. (1976) J. Biod. Chern. 2\$1, $2550-2563$.

18 Husaith, M., Schopfa, i.M. and Massey. V. (1978) Melhods Enzyuasl. 53, 54,3-559,

19 Matlet, F.. Yoordouw; G.. Van Beckel, W」.H., SIentris. P.J. Visker. S., and Vas Rocijen, P.J. (1979) Eur. J. Biochem. 101, 23.. 244 .

20 Hames, B.D. (1981) in Gel Elextrophoraxis of Proteins (Hankes. 8.D. and Riclwood, D., ads). Pp. 1-91, IRL Press, Oxford

21 Schopter, L.M. atd Massey, V. (1980) J. Biod. Chuth. 255, $5355-5363$

22 Beasy, N.B. and Ballon, D.P. (1981) J, \#iod, Chem. 256, 46II 4618.

23 Erisch. B. and Sim. R.G. (1983) And. Biochen. 193, 401-40B.

24 Mitlker, F. and Van Berket, W.I.H. t!1982) Eur. J. Bjocbem I28, 21-2?.

25 Van Berked, W.J.H. and Mültwr, F. (1989) Ear. J. Hiochers. 179, $307-314$.

26 Van der Lusn, J.M. Swatte M.B.A.. Groendijt, H., Hol. W.GJ. and Drentb, J. (1989) Eur. J. Gixchem. J79, J15-724.

27 Entsch. B., Baikou, D.P., Huessin. M. and Mnssey, V. (1976) d. Biol. Chem, 251, 3367-7579.

28 Husain $M$ and Massey. V, (7979) J. Bjol, Chem. 254, 6657-6666. 29. Drlziel, K. (1969) Biwethesn. J. 114, 547-556.

3C Husqin, M., Entech, B., Ballou, D.P., Musscy. v. and Chapman, P.J. (1960) J. BioL Chen. 255. 4 tR9-419?,

II Van der l,asis. J.M. \{1946) Doctora\} Disscriation, Unibersify of (imoningen, Netherlendx

32 Siricklanit, S., Paimer, G. and Massey. V. \{1975, I. Fiol, Chem. 250, 4048- 4052

33 Anderson. R.F., Patek, X.B. and Straticord, M.R.L. (that) J. Biot Chesn. 262, 17475-17479.

34 Wessiak, A., Schopftr, L.M. and Massey, V. (ISgd) J, Bind. Clnem. $259,12547-12556$.

35 Fies:ht, A (1985) Enayme Structure and Mechranisml, po. 293-346, W.H. Frocman Niw York.

36 Dickerson. RE and Geqis. I. (1983) Hermigyohis, pp. 125.145, Benjamio/Cummingàn Mento Park 